\title{
Management and Empowerment of Honorary (Non PNS) Teachers Madrasah State in Manado City
}

\author{
Asnandar Abubakar ${ }^{1}$, Amiruddin $^{2}$ \\ \{asnandar2.aja@gmail.com ${ }^{1}$, amiruddinalbarru@gmail.com² ${ }^{2}$.gm
}

Research \& development and Training Ministry of Religion Indonesian ${ }^{1}$, Research \& development and Training Ministry of Religion Indonesian ${ }^{2}$

\begin{abstract}
This study aims to see and describe the management and empowerment of honorary teachers in public madrasah in the city of Manado. This research is a qualitative study by describing data descriptively. The location of the study was conducted at madrasah in Manado City. Data analysis was carried out systematically which included organizing data, data categorization, and interpretation. Management of honorary teachers is carried out through planning for recruitment of honorary teachers based on an analysis of teacher needs, organizing by organizing tasks and responsibilities, as well as the authority of honorary teachers and given additional salaries and honorariums, implementation by directing the duties and functions of honorary teachers to run effectively and efficiently, and supervision of honorary teachers that is present on time, filling in attendance lists, preparing teaching materials, innovating in teaching students, fostering a harmonious family atmosphere and working atmosphere, building vertical and horizontal communication, and permits when unable to work. Empowerment of honorary teachers in madrasah is to provide teaching burdens in accordance with their duties and functions, give assignments as homeroom teachers, give responsibilities to extracurricular activities, give responsibilities to scout activities, carry out picket assignments, participate in madrasa program planning, participate in madrasah committee activities, and maintain orderliness of the teaching and learning process in madrasah.
\end{abstract}

Keywords: Honorary Teachers, Management, Empowerment

\section{Introduction}

Attention to improving the quality of education is inseparable from the attention of all aspects of the management of the education component, including the management and empowerment of honorary teachers. Honorary teachers have so far only been underestimated in the management of educational institutions and only as supporting and complementary factors in fulfilling the implementation of learning, even though it is undeniable that honorary teachers also play an active role and contribute greatly in improving the quality of competency of graduates of an educational institution.

The problematic of honorary teachers is that they continue to color the activities of the world of education in improving the professionalism and quality of management of educational institutions. Among these problems is not yet the maximum fulfillment of subject teachers in 
private madrasah (madrasah under the auspices of the foundation). Private madrasah still lack a subject teacher even though they have received the assistance of a civil servant teacher (PNS) from the government. The foundation that houses the madrasa requires the madrasa head to appoint honorary teachers. This will have implications for the responsibilities and burdens of the government (Ministry of Religion) in paying attention to the honorary teacher. Although the foundation that appoints honorary teachers but intensive or honorary teacher salaries is the responsibility of the Ministry of Religion.

Intensive for honorary teachers at the Ministry of Religion has been regulated through Decree of the Minister of Religion Number 1 of 2018. The intensive amount of an honorary teacher who does not yet have a teacher certification of IDR 250,000 one month or IDR $3,000,000$ one year. The budget issued by the government becomes large if calculated with the number of existing honorary staff.

This number will increase if it is not anticipated wisely by effectively analyzing teacher needs. Especially when associated with honorary staff as a whole, the budget that must be provided by the government to handle intensive / payroll reaches IDR 9 trillion every month [12].

The problem that often adorns the face of education in Indonesia is the lack of teacher welfare, especially honorary teachers, Chairperson of the Republic of Indonesia Teachers Association (PGRI), Sulistyo, assesses the employment status of honorary teachers is unclear. In fact, the salary received by honorary teachers is not feasible [12].

Honorary teacher competency is also a problem for managers of educational institutions. There are still honorary teachers who do not have a competency test (teacher certification), although it is not an absolute indicator in improving graduate competency. On the one hand educational institutions must provide quality learning, on the other hand educational institutions must meet the limitations of teachers and the budget, so that there are honorary teachers who work on subjects not in accordance with their field of expertise or educational background or there are teachers who work on two different subjects. The appointment of honorary teachers must be adjusted to the competency standards that have been set, such as educational qualifications must be at least S1 or D3, teachers who will be appointed at least have attended micro teaching.

In addition to educational qualifications and teaching experience, the appointment of honorary teachers must also pay attention to the availability of the budget and professional attitude. Teacher professionalism improvement must be supported by the fulfillment of welfare. Welfare is certainly related to the income of the teacher concerned. Educational institutions that house honorary teachers must prepare a budget as additional income for honorary teachers so that the enthusiasm for work, skills and abilities of teachers can be maximally devoted. And of course, it will have an impact on improving the quality of madrasah as a whole. The results of Unesco's research conducted by Cooper and Alvarado (2006) illustrate the main problems that arise in the recruitment of teachers, namely: (1) low status of teaching (as evidenced in some countries by very low salaries); and (2) the lack of appeal found in the profession. Teacher recruitment often encountered payroll constraints that were still minimal and lacked the expertise or professional competence as a teacher desired by educational institutions [12].

By maximizing the duties and functions of honorary teachers, managers of educational institutions will also be obliged to improve the quality of the human resources (HR) of honorary teachers. The increase in honorary teacher human resources can be done by involving education and training activities (Diklat) held by the central or regional government, including education workshops, to increasing educational qualifications. Schools need to improve the 
professionalism of subject teachers by including in education and training related to curriculum development and learning management [6].

Honorary teacher recruitment certainly does not all have low competencies, there are still many honorary teachers who have competencies in accordance with the standards set by the government, namely pedagogical competence, personality competence, professional competence, social competence, and leadership competence. Honorary teachers are aware to equip themselves both in aspects of knowledge, attitudes, skills and aspects of religiosity in the midst of so high competition to become a teacher. Armed with the high competencies possessed by honorary teachers will certainly increase self-confidence. High confidence will have a positive impact on the implementation of the learning process and the completion of teacher tasks effectively and efficiently. In the theory of self-efficacy (self-efficacy theory) proposed by Robbins and Judge (2015) revealed that each individual has the confidence to be able to carry out certain tasks assigned to him [12].

The maximum management and empowerment of honorary teachers will create a healthy and conducive climate and organizational culture of educational institutions so that the goals and programs of educational institutions can be optimally achieved. Therefore, research needs to be carried out on how to manage and empower honorary teachers in state educational institutions or madrasah? The purpose of this study is to see and describe the management and empowerment of honorary teachers in state educational institutions or madrasah.

\section{Literature review}

Honorary employee is a person who is officially appointed by the authorized official (work unit leader) and authorized by the Government Institution Staffing Officer to carry out certain tasks whose salary is given to the APBN and APBD [3].

Efforts to improve teacher competency are carried out through optimizing the strategic role of school principals as educators, managers, administrators, supervisors, leaders, creators of work climate, and entrepreneurship. The extent to which principals can realize these roles, can contribute to improving teacher competency, so that it can have an effect on improving school quality [14].

Discussion on honorary teachers has been conducted by Nugroho et al on the Performance of Honorary Teachers in Learning in Junior High Schools [6], Inspiration on Local Government Efforts to Minimize Unemployment Personnel through Government Regulation No.56 of 2012 [8] Concerning Appointment of Honorary Workers in Malang City [3], Hanifa et al on Decision Support Systems Determining Salary Amounts for Honorary Teachers in Pesawaran District Using the Fuzzy Saw Method [2], Jumriatunnisah and Hidayatullah on the Effect of Culture, Compensation and Internal Motivation on the Performance of Honorary Teachers At High Schools in Bima District [4].

The following discussion was conducted by Anam et al about the Effect of Principal Leadership and Organizational Culture on the Work Motivation of Honorary Teachers of Public Elementary Schools in the Selaparang District of Mataram City [1], Suryana on Strategies to Improve the Quality of Primary School Honorary Teachers in the Environment PGRI District Sukawening Garut [13], Mauna and Kurnia on the Effect of Perception of Social Support on Subjective Well-Being in Honorary Teachers of Public Elementary Schools in North Jakarta [5].

Honorary teacher capacity building is the ability to transform oneself so that the attitudes and activities undertaken can be accepted in the school and community environment. Adi W. 
Gunawan (2008) in Prastowo explains human Transformational Thinking which consists of three systems namely behavior systems, thinking systems, and belief systems [7].

\section{Methodology}

This research is a qualitative study that describes data descriptively to illustrate the phenomenon of research findings with the tendency of inductive analysis. This research will describe the problematic management and empowerment of honorary teachers in educational institutions or madrasah.

The research location was carried out in Manado City with a focus of research on honorary teachers in madrassas. The focus of the study aims to describe the core of the problem so that it does not cause much abstraction. Data collection techniques used in this study were observation, interviews, and documentation.

Data analysis was performed based on the form and nature of the data collected. Data analysis was carried out systematically which included organizing data, categorizing data, and interpreting it in accordance with the meaning and forms of reporting and then presented in a descriptive qualitative manner.

\section{Result and finding}

\subsection{Management of honorary teachers}

\subsubsection{Planning}

Planning is preparing something to achieve a certain goal. In planning the fulfillment of non-civil servant teachers (GBPNS) or non-civil servant teachers in madrasah in the city of Manado is carried out at the beginning of the year, namely at the annual meeting. But the procurement of honorary teachers can be done in the middle of the year if needed directly in accordance with the results of the needs analysis.

Madrasah heads continue to communicate with teachers in recruiting honorary teachers. Teachers are asked for opinions on subject teachers who are lacking or badly needed. The recruitment of honorary teachers is usually not announced but is only informed by teachers or madrasa heads who have relatives. Prospective honorary teachers come or apply directly to the headmaster. The headmaster of the madrasa will test both the files and the competencies possessed by prospective honorary teachers. If it is in accordance with what is needed, the madrasah head decides to directly accept the relevant honorary teacher.

The non-civil servant teacher who was accepted was not immediately made a decision letter (SK) acceptance at the madrasa, but beforehand devoted himself teaching about 1-2 months. After serving, an acceptance decree is made which is determined directly by the headmaster. The appointment of non-civil servant teachers is then conveyed to the Manado City Ministry of Religion through an annual report. Furthermore, after taking the long teaching period (2-3 years) continuously, honorary teachers can arrange the Sort Number of Educators and Education Personnel (NUPTK) in the Manado City Education Office as a condition to be registered in the 
SIMPTIKA application of the Ministry of Religion. Honorary teachers who have registered on the SIMPATIKA application can already take care of teacher certification.

In addition to being able to take care of teacher certification, honorary teachers who have obtained NUPTK and have registered at SIMPATIKA can get a teacher incentive allowance of Rp.250,000 according to the Decree of the Director General of Islamic Education Number 484 of 2018 concerning Technical Instructions for Providing Incentive Allowances for Non-Civil Servant Teachers to Madrasa. For honorary teachers in private madrasah, the payroll system is managed through a foundation that houses the madrasa.

NUPTK is the official identity number of a teacher that can be used for the purpose of identifying data in various implementation of programs and activities related to improving the quality of educators and education staff. To get NUPTK, teacher data must be verified and validated and inputted through the SIMPATIKA application. For the proposed teacher certification there is an academic selection for Teacher Professional Education (PPG).

\subsubsection{Organizing}

Organizing is a process carried out to regulate the duties and responsibilities, as well as the authority of non-civil servant teachers in Madrasah. Honorary teachers in madrassas in Manado City, besides being given assignments according to their tasks and duties, namely teaching, are also given additional assignments, such as homeroom teachers, extracurricular supervisors such as scouts, committees in madrasa activities such as new student admissions, and daily picket assignments.

All additional activities given to honorary teachers receive intensive or honorarium from each madrasah headmaster in addition to the fixed monthly salary received. Honorary teacher month salaries come from Madrasah DIPA and Madrasa Committee. Monthly salary is IDR $1,700,000$ and committees are in the range of IDR $1,700,000$. The monthly salary of the committee is calculated based on teaching hours.

The policy to appoint honorary teachers is still the responsibility of the madrasa head. Although there are many honorary teachers recruited from the friendship process, teacher competency remains a major concern. Subsequent admissions will be held through tests or ability tests based on competence as a teacher. Honorary teachers who have been accepted will be increased in competence. Competency improvement is carried out through education and training, participating in teacher workshops, maximizing subject teacher deliberations (MGMP) or teacher working groups (KKG).

Honorary teachers carry out teaching duties and are also responsible for instilling character in students. In Madrasah Ibtidaiah Negeri (MIN), honorary teachers are given responsibility as class teachers. Honorary teachers are responsible for improving the quality of morals, attitudes, and behavior of students for the better. Class teachers teach all subjects or thematic, Problems arise because most teachers have a background in Islamic religious education, many honorary teachers have graduated from the State Islamic Institute (IAIN). Honorary teachers must find ways to improve their competence in order to teach subjects other than Islamic subjects.

Honorary teacher welfare through this salary is considered to be lacking. To anticipate this, the madrasa head adopted a policy of giving IDR 200,000 a month, and during the month of

Ramadan they are sent back an hour earlier than a PNS teacher. Honorary teacher competencies will improve if welfare increases. Honorary teachers must focus on carrying out their duties, not 
doing madrasa administration tasks. This is done to show the quality to the community. The quality in question is the quality of the institution or madrasa in general and the quality of graduate students specifically. By showing quality, people will believe in madrassas to send their children to school.

With this trust, the community will not hesitate to help madrasah both financially and contribute to the thinking of actual programs related to improving madrasa quality. The use of madrasah budget obtained through the community (madrasah committee) is used to finance madrasah activities, one of which is the budget for the go green school and friendly school program.

The next organization of honorary teachers is to determine and pay attention to the tasks and authorities according to their functions. Duties and authority of class teachers / subject teachers in class management are managing classrooms, arranging classrooms, creating a teaching and learning climate based on harmonious and healthy human relations, implementing classroom administration by recording student data management, student mutations, student attendance lists, division of student assignments, data on handbooks, timesheets and graphs, class inventory.

The task and authority of the class teacher/ subject teacher in the teaching and learning process is to make enrichment programs, make teaching preparations by paying attention to methods and process skills that are relevant to the material and students in order to develop skills. Carry out guidance and practice of worship for students.

Duties and authorities of class teachers / subject teachers related to self-development are to use appropriate methods or media sources, make simple tools, motivate students to use existing facilities, develop teacher professional abilities, be fully accountable to the headmaster in carrying out general education and class coaching specifically, and fostering good cooperation with all elements involved in the development of madrasah education.

\subsubsection{Implementation}

Implementation is the process of realizing plans that have been agreed upon, and managed to achieve the goals. In the management of honorary teachers, the headmaster of madrasah in the city of Manado conducts constructive relations and effective communication with honorary teachers so that in carrying out the tasks can run efficiently and effectively. The madrasah head is fully responsible for the implementation of teaching and learning activities by honorary teachers. Madrasah principals are required to maximize managerial functions in managing honorary teachers. The madrasah head must have the spirit and character of a strong leadership in carrying out its policies.

Effective leaders are honest leaders, devotion to God Almighty, integrity, physical and mental vitality, intelligence, wisdom, responsibility, competent, understanding the needs of followers, interpersonal skills, the need to participate, able to motivate and encourage, be able to solve problems, convincing, has the capacity to win, has the capacity to manage-decidedetermine priorities, be able to hold trust, have influence, be able to adapt or have flexibility [11].

According to Hersey and Blanchard (in [11]) the relationship between leaders and members there are four stages, namely: (1) the initial stage of readiness of the leader's attention to the task 
is very high, members are given clear instructions and familiarized with rules, structures, and procedures work, (2) members are able to handle tasks, but have not been able to work without being structured, (3) members have greater ability and achievement motivation begins to appear and actively seek greater responsibility, leaders do not need to give direction, and (4) members begin to be confident, self-directed and experienced. The leader has reduced attention and direction.

Head of MAN 1 Kota in managing madrasah running 5W1H (what, where, when, who, why, and how). What must be done for honorary teachers to have a good performance, where the effective position of a honorary teacher can contribute to madrasah, when to approach honorary teachers so that communication can run effectively, who should take the initiative in implementing madrasah quality improvement programs, why should breakthrough programs and how to run madrasah programs efficiently and effectively so that educational goals can be achieved.

In the implementation of madrasah activities programs, the madrasah head builds communication with all elements of education, both with the community, parents of students, or teachers. Through this communication, the community and parents of students obtain information about the quality of madrasah facilities and infrastructure, the competencies and educational qualifications of honorary teachers (most already have masters level masters), and the quality of instructional technology media. One of the learning media used is a projector. With a projector, honorary teachers can deliver lessons clearly, can play videos, learning pictures, or with sound.

The madrasah head changes the vision and mission of the madrasah and the madrasah guidelines starting with the discipline of teachers and students, admission of new students, religious activities, sports and arts, and the KKM (minimum completeness criteria) requirements. The aim is to improve the quality of madrasah. The madrasah head also made other breakthroughs to improve the quality of madrasah, including changing the policy of the previous madrasah head and working based on regulations. Especially the admission of new students, the rules are tightened according to regulations such as prospective students must be able to at least read and write the Qur'an, must pass the first test and the second test. This madrasah head's policy, fully supported by the Head of the Regional Office of the Ministry of Religion of North Sulawesi Province.

There are 30 honorary teachers in public madrasah, these teachers are given salary through DIPA and the Madrasah Committee. Honorary teachers who are paid through DIPA are teachers who have served three or four years and have been proposed for certification. In the last ten years there were no additional teachers in MAN and MTsN, retired teachers were replaced by honorary teachers whose qualifications and competencies match the needs of the subjects. Public Madrasah still lack teachers, especially Arabic, English, Indonesian, Chemistry, Japanese. For this year, MAN received 13 civil servant candidates. Even so MAN 1 still lacks teachers, especially social studies, history, and sociology teachers.

\subsubsection{Supervision/evaluation}

Planning is preparing something to achieve a certain goal. In planning the fulfillment of non-civil servant teachers (GBPNS) or non-civil servant teachers in madrasah in the city of Manado is carried out at the beginning of the year, namely at the annual meeting. But the 
procurement of honorary teachers can be done in the middle of the year if needed directly in accordance with the results of the needs analysis.

Supervision / evaluation of honorary (non PNS) teachers conducted by the madrasah head refers to existing government regulations or regulations, including Minister of National Education Regulation No. 19 of 2007 which states that the evaluation process of educators and education personnel includes: (a) evaluation of the utilization of educators and educational staff are planned comprehensively at the end of each semester with reference to the Standards of Educators and Education Personnel, (b) evaluation of the utilization of educators and education personnel including the appropriateness of assignments with expertise, workload balance, and the performance of educators and education personnel in carrying out tasks. And (c) evaluating the performance of educators must pay attention to the achievements and changes in students.

Supervision conducted by the madrasah head of honorary teachers is present on time, filling the attendance list, preparing teaching materials, being innovative in teaching students, fostering a family feel and harmonious working atmosphere, building vertical and horizontal communication, permitting when unable to work, and honorary teachers must have a sincere intention in working or carrying out their duties.

The next oversight carried out by the headmaster is the development of attitudes of honorary teachers, namely whether honorary teachers; make preparations before carrying out learning; come to teach on time and be in the school environment every day; conduct regular teaching evaluations; participate in maintaining and maintaining school rules; participate in fostering good relations between the community and schools; behave in accordance with teacher ethics, help smooth the course of education; fostering and communicating tri education centers (schools, homes, and communities); must teach, guide, educate, and train students based on their competencies.

\subsection{Empowering of honorary teachers}

Empowerment is a process of activity and development, as well as attention to honorary teachers in carrying out their duties and functions in madrasah. Empowerment of honorary teachers in madrasah is to provide teaching burdens in accordance with their duties and functions, give assignments as homeroom teachers, give responsibilities to extracurricular activities, give responsibilities to scout activities, carry out picket assignments, participate in madrasah program planning, participate in madrasah committee activities, and maintain orderliness of the teaching and learning process in madrasah.

Honorary teachers assigned as homeroom teachers receive an additional Rp.600,000 honorarium, as well as honorary teachers who receive an additional task of developing extracurricular members receive an honorarium of Rp. 600,000 per month. Honorary teachers who are already inpassed receive a salary of Rp. 2,500,000. Honorary teachers who are on the new student admission committee also receive an additional honorarium. Non civil servant teachers get picket schedules, tasked with supervising students entering madrasah and keeping a daily journal. The duty of picket also received an honorarium.

In MTs 1 Manado, a good honorary teacher is made the homeroom teacher. Honorary teacher fees are paid through DIPA. Honorarium from DIPA IDR 1,700,000 while from the madrasa committee IDR 16,000 every hour. Honorary teachers receive 13th salary and holiday allowances, although not as much as the 13th salary. Honorary teachers receive an additional honorarium through activities carried out by madrassas. An additional non-civil servant 
teacher's honorarium is obtained from assignments as a school picket once a week for IDR 100,000 each month. Honorary teachers who get assignments as homeroom teachers get IDR 200,000 every month. Honorary teachers who are assigned as extracurricular supervisors also receive an additional honorarium. The process of accepting honorary teachers in madrasas, namely honorary teachers, personally came to register and be tested directly by the madrasa headmaster. Honorary teachers are also involved in madrasa program planning, involved in annual meetings, and involved in the madrasa certification team. Education and training that have been attended by honorary teachers include the education and training of mathematics subjects. Education and training curriculum K13, education and training in Islamic religious education, and education and training in learning methods.

In MIN 1 Manado, honorary teachers created an in passed group as a place to share information. Honorary teachers who are already in passed no longer receive certification allowances even though they are certified. Honorary teachers who get additional duties as extracurricular responsible get a fee of Rp.400,000 every month. There were three honorary teachers who received additional intensive functional allowances for teachers of IDR 250,000. Education and training that have been followed by honorary teachers are basic madrasas. The process of accepting honorary teachers in MIN 1 Manado is by applying for themselves, getting teacher acceptance information from friends.

In MIN 2 Manado, non-certified civil servant teachers receive an allowance of IDR $1,500,000$ every month and get a transportation fee of IDR 7,500 every day. Honorary teachers who are given additional duties as homeroom teachers receive an honorarium of IDR 50,000 per month. There are also honorary teachers who receive intensive teacher allowances of IDR 250,000 from the Ministry of Religion. Honorary teachers are involved in madrasa activities, annual meetings, and take responsibility for implementing madrasa programs. The additional activity of honorary teachers is participating in the teacher working group (KKG). Education and training ever attended by honorary teachers is the K13 curriculum and classroom teachers.

\section{Conclusions}

In the management and empowerment of honorary teachers, madrasah principals must have the ability to manage situations, strive to improve achievement starting with improving welfare, embracing all, togetherness, comfort, making innovations and breakthroughs in empowering honorary teachers, for example making homeroom teachers and other tasks.

Management of honorary teachers in madrasah in Manado City includes: planning of honorary teachers, Analysis of the needs of honorary teachers, procurement of honorary teachers, orientation, Placement and Assignment, Compensation or payroll, Performance appraisal, no career development, lack of training and teacher development non civil servants, the absence of quality work life creation,

Honorary teacher empowerment in educational institutions or madrasah is the use and development of the ability of honorary teachers in carrying out the programs and objectives of madrasah. In addition to being burdened with teaching, honorary teachers are also required to do additional tasks such as those in charge of extracurricular activities.

Honorary teacher expectations are prioritized to be appointed as civil servants and not tested together with new graduates. Teacher competency development is to take part in education and training such as education and training curriculum 2013 (K13). Other expectations include education and training of subject honorary teachers. Honorarium must be increased the same as the honorarium of administrative staff or temporary employees. Honorary teachers also hope to 
be included in the scholarship program to improve education. Honorary teachers also expect to receive holiday allowances and 13th salary, the reason being that the duties of honorary teachers are the same as civil servant teachers.

Acknowledgements. The author would like to express my gratitude and highest appreciation to all those who have helped the writer during the research. The author also thanks the Head of Research and Development Religious of Makassar for giving the author the opportunity to conduct research. And the authors would like to thank the sincerity of my fellow researchers to accompany the authors in discussions and provide input and criticism during this writing.

\section{References}

[1] Anam, M Chairul, Sudirman Wilian, and Dadi Setiadi. 2016. "Pengaruh Kepemimpinan Kepala Sekolah Dan Budaya Organisasi Terhadap Motivasi Kerja Guru Honorer Sekolah Dasar Negeri Di Kecamatan Selaparang Kota Mataram.” Jurnal Ilmiah Profesi Pendidikan 1 (1): 63-76.

[2] Hanifa, Muhamad Muslihudin, and Sri Hartati. 2016. "Sistem Pendukung Keputusan Menentukan Besar Gaji Untuk Guru Honorer Di Kabupaten Pesawaran Menggunakan Metode Fuzzy Saw.” Jurnal Teknologi 9 (01): 83-88.

[3] Ilham. 2017. "Upaya Pemda Memanimalisir Tenaga Pengangguran Melalui PP No.56 Tahun 2012 Tentang Pengangkatan Tenaga Honorer Di Kota Malang." Nuansa, Jurnal Ilmiah Pendidikan VI (1): n.p.

[4] Jumriatunnisah, Nur, and Muh Hidayatullah. 2017. "Pengaruh Budaya, Kompensasi Dan Motivasi Internal Terhadap Kinerja Guru Honorer Pada Sekolah Menengah Atas Di Kabupaten Bima." Jurnal Tambora 2 (3): n.p.

[5] Mauna, and Puspa Irmandari Kurnia. 2018. "Pengaruh Persepsi Dukungan Sosial Terhadap Subjective Well Being Pada Guru Honorer Sekolah Dasar Negeri Jakarta Utara.” Jurnal Penelitian Dan Pengukuran Psikologi 07 (2): 77-82.

[6] Nugroho, Natanael Tri Pasetyo Adi, Rohiat, and Puspa Djuwita. 2017. "Kinerja Guru Honorer Dalam Pembelajaran Di SMP.” Manajer Pendidikan 11 (1): 8-19.

[7] Prastowo, Andi. 2015. "Prosiding Seminar Nasional 9 Mei 2015 Perubahan Mindset Dan Kesiapan Guru Sekolah Dasar Dalam Persaingan Pendidikan Di Era MEA,” 626-41.

[8] Peraturan Pemerintah Nomor 56 Tahun 2012 Tentang Perubahan Kedua atas Peraturan Pemerintah Nomor 48 Tahun 2005 Tentang Pengangkatan Tenaga Honorer Menjadi Calon Pegawai Negeri Sipil.

[9] Rivai, Veithzal. 2006. Kepemimpinan dan Prilaku Organisasi. Jakarta. PT.RajaGrafindo Persada.

[10] Rohman, Miftahur. 2016. "Problematika Guru Dan Dosen.” Cendikia 14 (1): 50-71.

[11] Setiawan, Aditya Chandra. n.d. "Guru Sebagai Pengajar Atau Pengelola Sekolah," 134-44.

[12] Sunandar, Asep. n.d. "Sistem Rekrutmen Dan Manajerial Kompetensi Guru Honorer," 36-45.

[13] Suryana. 2016. "Strategi Meningkatkan Mutu Guru Honorer Sekolah Dasar Di Lingkungan PGRI Kecamatan Sukawening Garut.” Jurnal Ecodemica 4 (2): 259-69.

[14] Wijaya, David. 2009. "Manajemen Sumber Daya Manusia Pendidikan Berbasis Kompetensi Guru Dalam Rangka Membangun Keunggulan Bersaing Sekolah.” Jurnal Pendidikan Penabur 8 (12): 69-86. 